компетенций различных стран преимущественно включают следующие составляюшие: применение циифровых технологий в профессиональном педагогической среде; владение профессиональными навыками поиска, создания и совместного использования циифрового образовательного контента; применение циифровых инструментов в обучении и преподавании; владения цифрровьли инструментами и стратегиями оченки результатов обучения; использование ичифровых инструментов для расширения образовательных возможностей учащиххя; безопасность при применении циифровых технологий.

ключевые слова: компетентность, циифровая компетентность, ичирровые технологии, рамка цичфровой компетентности, модель.

HENSERUK H. R. Digital competence of future teachers: foreign experience.

Different approaches of foreign scientists to interpret the concept of "digital competence" and identify the components of digital competence of future professionals have been discussed in the article. An analysis of the recent work of scientists on the problem has been conducted. The European standards for determining digital competence, the Digital Competence of Educators (DigCompEdu) teacher's digital competence framework have been analyzed. In the article the approaches to the description of the components of the digital competence of teachers have been highlighted. Frameworks for digital competencies in different countries have been developed. The digital competence of future teachers is important and implies the ability to use digital technology logically and systematically. It contributes to the success of the future specialist, the solution of various tasks and the formation of his important life competencies.

The list mainly includes the following components: the usage of digital technologies in a professional pedagogical environment; the mastering of the professional skills of finding, the creating and sharing digital educational content; the usage of digital tools in teaching and studying; the mastering of digital tools and strategies for evaluating learning outcomes; the usaage of digital tools to enhance students' educational opportunities; the security when using digital technologies.

Keywords: competence, digital competence, digital technologies, digital competence framework, model.

DOI: https://doi.org/10.31392/NZ-npu-144.2019.07

УДК 377.091.12.011.3-051:005.336.5

Гриженко В. В.

\title{
ПЕДАГОГІЧНЕ ПРОЕКТУВАННЯ ЯК ПЕДАГОГІЧНА УМОВА РОЗВИТКУ ФАХОВИХ КОМПЕТЕНТОСТЕЙ ВИКЛАДАЧІВ ЗАКЛАДІВ ПРОФЕСІЙНО-ТЕХНІЧНОЇ ОСВІТИ
}

У статті розкрито сутнісні характеристики педагогічного проектування як педагогічної умови розвитку фахових компетентостей викладачів закладів професійно-технічної освіти. Охарактеризовано особливості проектної діяльності для викладачів закладів професійно-технічної освіти. Представлено різні погляди вчених на суть досліджуваного поняття. Визначено приниипи педагогічного проектування. Доведено важливість використання технологій педагогічного проектування у професійно-технічних навчальних закладах. Виокремлено структурні компоненти педагогічного проектування.

Ключові слова: педагогічне проектування, педагогічна умова, викладач, професійно-технічна ocвima.

У контексті знаходження відповідей на виклики сучасності та, зважаючи на трансформаційні і модернізаційні зміни в сучасній системі освіти України, в професійно-технічній освіті виникають проблеми розвитку фахових компетентностей викладачів. В умовах, коли змінюється освітня стратегія, 
фахові компетентності викладача набувають надзвичайної актуальності. Стрімкий розвиток сучасних технологій і засобів навчання, інноваційних фоом підготовки робітничих кадрів вимагає від сучасного викладача здійснювати педагогічну діяльність компетентно, професійно, якісно. Крім своїх функціональних обов'язків, сучасний викладач сьогодні повинен володіти сучасними інформаційними технологіями, знаннями новітніх досягнень та постійно підвищувати свій методичний рівень. Тому виникає потреба у пошуку і впровадженні таких педагогічних умов, за яких би фрахові компетентності викладачів закладів професійно-технічної освіти вийшли на якісно високий рівень і позитивно впливали на підготовку робітничих кадрів.

Результати аналізу психолого-педагогічної літератури, в якій відображено наукові здобутки щодо вивчення компонентного і змістового складу фахових компетентностей викладачів, демонструють значний інтерес вітчизняних і зарубіжних дослідників до зазначеної проблеми. Засади і принципи сучасної системи неперервної професійної освіти розглядають у своїх працях С. Гончаренко, Г. Балл, Н. Ничкало, В. Семиченко, Л. Пуховська. Психологопедагогічним закономірностям організації навчально-виховного процесу присвячені праці Р.Гуревича, А. Лігоцького, О.Пєхоти. На важливості професійно значущих якостей особистості педагога наголошують А. Алексюк, Ю. Бабанський, Т. Ільїна, А. Маркова, В. Сластьонін, О. Щербак. Водночас зазначимо, що недостатня увага приділена педагогічним умовам розвитку фахових компетентностей викладачів закладів професійної (професійнотехнічної) освіти. Тому вважаємо, що педагогічне проектування як педагогічна умова розвитку фахових компетентостей викладачів закладів професійнотехнічної освіти становить науковий інтерес для підвищення якості професійної підготовки викладачів закладів професійно-технічної освіти.

Мета статті полягає в розкритті сутнісної характеристики педагогічного проектування як педагогічної умови розвитку фрахових компетентостей викладачів закладів професійно-технічної освіти.

Застосування проектних технологій в професійній освіті $€$ досить актуальним питанням сьогодення, зокрема для викладачів практичного навчання. Для професійної освіти надзвичайно ефективними $є$ проектні технології, оскільки вони надають можливість підготуватися до якісної реалізації професійних функцій. Наразі проектна діяльність визнана основною стратегією розвитку освіти XXI сторіччя. Проектна робота передбачає використання викладачем сукупності дослідницьких, пошукових, творчих за своєю суттю методів, прийомів, засобів.

На думку О. Дубасенюк, проектування у педагогічній діяльності виконує роль провідного регулятора всієї системи дій педагога протягом всього періоду його діяльності. Діяльність педагога має випереджальний характер і виступає у двох формах - передбачення (прогнозування, антиципації) і цілепокладання, що дає можливість керувати процесом в умовах динамічного середовища [3, с. 44].

Для цього необхідно конструювання педагогом як власної діяльності, так проектування діяльності учнів, учнівського колективу, що відбувається шляхом 
аналізу, підготовки та розробки дидактичних проектів на рівні спеціальності, навчальної дисципліни, розділу та конкретної теми, розробки проектів проведення дидактичних, виховних та інших заходів, визначення педагогом оптимальних форм, методів і напрямів подолання життєвих і професійних криз.

Проблема педагогічного проектування досліджувалась у руслі компетентністного підходу (В. Беспалова, Е. Зеєр, А. Тряпіцина); як спосіб реалізації інноваційної педагогічної діяльності у контексті підвищення якості вищої освіти (О. Литвиненко, Н. Плахотнюк); виявлялись теоретико-методичні засади проектування та їх технологічне забезпечення через систему проектів (Л. Савченко, Т. Ткач).

У вітчизняній педагогічній науці педагогічне проектування трактується як самостійна поліфункціональна педагогічна діяльність, обумовлює створення нових або перетворення наявних умов процесу виховання і навчання В.Литвиненко визначає педагогічне проектування як цілеспрямовану поліфункціональну педагогічну діяльність зі створення теоретико-методично обґрунтованих проектів - інноваційних моделей цілісного навчального процесу, спрямованих на якісний результат професійного розвитку і саморозвитку фахівців [5].

О. Безпалько визначає проектування як багатокрокове планування, як діяльність по визначенню умов реалізації конкретної педагогічної системи [2].

$€$. Алісов розглядає педагогічне проектування у вигляді самостійної поліфункціональної педагогічної діяльності, спрямованої на створення нових або перетворення наявних об'єктів сфери освіти у відповідь на потреби, що виникають у процесі розвитку людини, суспільства, культури або самих освітніх систем [1].

Ми розглядаємо педагогічне проектування не тільки як функцію педагога, а й як педагогічну умову розвитку фахових компетентостей викладачів закладів професійно-технічної освіти. За умови педагогічного проектування у діяльності викладачів відбувається актуалізація складової частини їх компетентності, що включає розробку, прогнозування, планування результатів професійної діяльності. Для проектування також характерна конструктивність, тобто націленість на отримання абсолютно певного практично значущого результату на основі прогностичного знання. Цим проектна діяльність відрізняється від простого виявлення та опису загальних педагогічних закономірностей, властивих, наприклад, науково-педагогічної діяльності. Можна наголошувати, що педагогічне проектування $€$ таким видом діяльності викладача, який має безпосередні зв'язки з іншими видами його педагогічної діяльності та визначає її ефективність.

Аналіз сучасної педагогічної літератури дозволяє говорити про існуючі в теорії та практиці різні класифікації педагогічних проектів. Разом з тим, вивчення теорії досліджуваної проблеми та аналіз педагогічних проектів, які існують і реалізуються в педагогічній дійсності, дозволили Т. Подобєдовій виділити наступні види педагогічних проектів [6]: 
- соціально-освітні проекти: проектування освітніх систем і процесів; проекти життєвої стратегії особистості, учнівських та педагогічних колективів;

- навчальні проекти: навчальні завдання і ситуації, методи проектів на конкретних уроках; проекти індивідуальних навчальних програм;

- виховні проекти: проекти в системі розвитку життєвої та діяльнісної компетентності учнів, їх соціалізації;

- культурологічні проекти;

- технологічні проекти: творчі мережеві проекти в навчальному закладі; проекти технологій навчання;

- дослідницькі проекти: ігрові, інформаційні, телекомунікаційні, комп'ютерні;

- індивідуальні, групові та колективні проекти: особистісно-орієнтовані, індивідуально-творчі, колективно-творчі.

Проектування як діяльність і технологія має організовуватися 3 дотриманням таких дидактичних принципів:

- принцип взаємозв'язку навчання, виховання і розвитку (розвиток інтелектуальної, емоційно-вольової, діяльнісно-поведінкової сфери особистості, залучення до різних видів навчально-пізнавальної діяльності 3 метою цілеспрямованого розвитку загальних і спеціальних здібностей, пізнавальних інтересів та потреб у саморозвитку та вдосконаленні);

- принцип гуманізації (утвердження особистості учня як найвищої соціальної цінності, найповніше розкриття його здібностей, нахилів, уподобань, задоволення особистісних освітніх потреб);

- принцип науковості (формування наукового світогляду відповідно до сучасного рівня розвитку науки);

- принцип оптимізації (вибір та реалізація найкращого варіанту організації самостійної навчально-пізнавальної діяльності учнів з урахуванням конкретних умов, необхідних умов для педагогів, учнів та їх реальних можливостей для здобуття максимально можливих результатів);

- принцип мотивації навчально-пізнавальної діяльності учнів (створення умов, за яких учень займає активну особистісну позицію і найбільш повно розкривається як суб'єкт навчально-пізнавальної діяльності);

- принцип активності свідомості та самостійності учнів (спонукання учнів до цілеспрямованої самостійної навчально-пізнавальної активності).

Педагогічні принципи зумовлюють вибір технології проектування, його змістового алгоритму, який визначає певну послідовність змістових дій щодо створення моделей-образів процесу навчання, його окремих модулів.

Необхідність проектування педагогічної діяльності педагога зумовлена, на нашу думку, низкою причин. По-перше, кардинальними змінами на ринку праці, коли сучасний кваліфікований робітник має бути мобільним, готовим до зміни місця праці, а іноді і спеціальності. По-друге, необхідністю поступового переходу ПТНЗ на гуманістичні парадигми професійного навчання і виховання майбутніх кваліфікованих працівників, одним із перспективних підходів $є$ суб’єктно-діяльнісний. По-третє, необхідністю формування творчого суб'єкта 
майбутньої професійної діяльності, оскільки педагог-гуманіст не нав'язує своєї позиції учневі: адже він не тільки сприймає його, а й поважає його думку, ставлення та цінності. Це виражається у шануванні особистої гідності учня; у врахуванні, наскільки це можливо, його уподобань і бажань при визначенні або конкретизації цілей навчання і способів їх досягнення.

Погоджуємося 3 думкою О. Коберника, що систему проектування навчального процесу характеризують такі ознаки: цілісність - відсутність зведення системи до суми утворюючих її частин, сприймання і розгляд їі як єдиного цілого; структурність - зв'язки і відношення елементів системи упорядковуються в деяку структуру, яка визначає функціонування системи; взаємозв'язок системи з середовищем; ієрархічність - кожний компонент може розглядатися як система, до якої входить інша; багатоваріантність описування - кожна система, що представляє собою складний об'єкт, у принципі не може бути зведена лише до якоїсь однієї картини, одного відображення, а може бути описана багатьма способами [4].

Розуміючи педагогічне проектування як цілісний процес зміни освітнього середовища професійної підготовки, у дослідженні ми будемо опиратися на його структурні компоненти: прогнозування, моделювання, конструювання та реалізації. Прогнозування як компонент проектувального процесу передбачає обґрунтування припущень про доцільність та хід зміни об'єкту проектування та виокремлення можливих шляхів його удосконалення. Моделювання розробка загальної стратегії зміни освітнього середовища професійної підготовки майбутніх учителів початкової школи на основі створеної моделі інноваційного проекту. Конструювання - подальша деталізація обґрунтованої моделі та створення реального об'єкта і наближення його до використання в системі профресійної освіти.

Специфічною особливістю проектної діяльності для викладача $€$ її активізуючий вплив на розвиток творчої спрямованості особистості і забезпечення творчого характеру сприйняття та аналізу об'єктивної дійсності (реальних явищ та процесів). Головним при використанні методу педагогічного проектування $€$ те, що теоретичні знання та їх практичне застосування органічно поєднуються. Педагогічне проектування має обов'язково відповідати таким критеріальним вимогам: дослідницький характер пошуку шляхів розв'язання проблеми; практична та теоретична, пізнавальна значущість прогнозованих результатів; наявність освітньої проблеми, складність та актуальність якої відповідає навчальним запитам, життєвим потребам, інтересам та віковим особливостям учасників проекту; створення умов для виявлення і розв'язання психолого-педагогічної проблеми; самодіяльний характер творчої активності; педагогічна цінність діяльності; використання активних та інтерактивних форм і методів.

Здійснюючи власну проектну діяльність, викладач повинен враховувати наступні вимоги: відповідність професійним стандартам / стандартам професійно-технічної освіти; відповідність змісту освітньої програми вимогам ринку праці; дотримання оптимального переліку складових професійної 
компетентності; відповідність змісту результатів навчання складовим профресійної компетентності; достовірність забезпечення зв'язків між результатами навчання та навчальними дисциплінами; дотримання логічної послідовності вивчення дисциплін; відсутність дублювання змісту навчання в різних дисциплінах.

Переконливою для нашого дослідження $\epsilon$ думка В.Ягупова, який стверджує, що у педагогічному проектуванні викладач реалізує, як правило, такі дії: 1) розробка замислу; 2) постановка цілей з урахуванням таких аспектів - соціальне замовлення на підготовку кваліфікованого працівника, особистість педагога як суб'єкта педагогічної діяльності, особистість учня як суб'єкта навчальної та майбутньої професійної діяльності; 3) збір необхідної інформації, розробка перспективних моделей дій і відбір засобів щодо реалізації визначеної мети, які забезпечуватиме їі досягнення; 4) динамічне структурування своєї педагогічної діяльності та навчальної діяльності учнів; 5) обмірковування варіантів розвитку взаємодії суб'єктів у процесі навчання педагогів і учнів; 6) організація зворотного зв'язку шляхом поточного регулювання та корекції своїх дій і навчальної діяльності учнів; 7) діагностика результатів педагогічної взаємодії щодо реалізації проекту; 8) підсумкова діагностика рівня розвитку об'єкта, співставлення його з прогнозованим, розробка проекту для нового етапу розвитку об'єкта 9) оформлення процесу та результатів проектування, повідомлення, публікація [7].

Враховуючи зазначені дії, вважаємо, що цей перелік повною мірою впливає на розвиток фрахових компететностей викладачів закладів професійно-технічної освіти, його структурні компоненти: прогнозування, моделювання, конструювання та реалізації.

Отже, педагогічне проектування виступає такою педагогічною умовою розвитку фахових компетентостей викладачів закладів професійно-технічної освіти, за якої вирішується ціла низка різнорівневих дидактичних, виховних і розвивальних завдань, відбувається соціальний та інтелектуально-творчий розвиток всіх суб'єктів професійно-технічної освіти, фрормування високоінтелектуальної, компетентної, свідомої особистості з громадянською позицією, здатної до самореалізації та прояву своїх можливостей у різних сорерах діяльності. Педагогічне проектування здійснюється викладачами 3 урахуванням соціокультурного контексту аналізованої проблеми, в якому повною мірою розвиваються соціально-культурні, психолого-педагогічні, техніко-технологічні та організаційно-управлінські компетентності викладачів закладів професійно-технічної освіти.

\section{Використана література:}

1. Алисов Е. А. Педагогическое проектирование экологически безопасной среды : дис. ... доктора пед. наук : 13.00.01. Курск, 2011. 405 с.

2. Безпалько О. В. Формування готовності студентів педвузу до проектування організаційних форм виховної діяльності : дис. ... канд. пед. наук: 13.00.01. Київ, 1998. 190 с.

3. Дубасенюк О. А. Фактори продуктивності професійної педагогічної діяльності вчителя. Акмеологія шкільної освіти : науково-методичний посібник / за заг. ред. Г. С. Сазоненко. Київ : “Основи”, 2010. 560 с. С. 142-150. 
4. Коберник О. М. Проектування навчально-виховного процесу в школі. Київ : Хрещатик, 1995. $153 \mathrm{c}$.

5. Литвиненко О. В. Професійно-педагогічне проектування навчального процесу у ВНЗ. Вісник ЛНУ імені Тараса Шевченка. 2012. № 22(257). Ч. V. С. 43-48.

6. Побєдова Т. Ю. Автореф. дис. ... канд. пед. наук : 13.00 .04 / Луган. нац. пед. ун-т ім. Т. Шевченка. Луганськ, 2005. 20 с.

7. Ягупов В. Методолгія модернізації професійно-технічної освіти України. Науковий вісник Інституту професійно-технічної освіти НАПН України. Сер.: Професійна педагогіка. 2011, № 1. C. 87-93.

\section{References:}

[1] Alysov E. A. Pedahohycheskoe proektyrovanye эkolohychesky bezopasnoi sredы : dys. ... doktora ped. nauk : 13.00.01. Kursk, 2011. $405 \mathrm{~s}$.

[2] Bezpalko O. V. Formuvannia hotovnosti studentiv pedvuzu do proektuvannia orhanizatsiinykh form vykhovnoi diialnosti: dys... kand.ped.nauk: 13.00.01 / Bezpalko Olha Volodymyrivna. Kyiv, 1998. $190 \mathrm{s.}$

[3] Dubaseniuk O. A. Faktory produktyvnosti profesiinoi pedahohichnoi diialnosti vchytelia. Akmeolohiia shkilnoi osvity: naukovo-metodychnyi posibnyk / za zah. red. H. S. Sazonenko. Kyiv : "Osnovy”, 2010. 560 s. S. $142-150$.

[4] Kobernyk O. M. Proektuvannia navchalno-vykhovnoho protsesu v shkoli. Kyiv : Khreshchatyk, 1995. 153 s.

[5] Lytvynenko O. V. Profesiino-pedahohichne proektuvannia navchalnoho protsesu u VNZ. Visnyk LNU imeni Tarasa Shevchenka. 2012. № 22(257). Ch. V. S. 43-48.

[6] Pobiedova T. Iu. Avtoref. dys... kand. ped. nauk : 13.00.04 / Luhan. nats. ped. un-t im. T. Shevchenka. Luhansk, 2005. $20 \mathrm{~s}$.

[7] Yahupov V. Metodolhiia modernizatsii profesiino-tekhnichnoi osvity Ukrainy. Naukovyi visnyk Instytutu profesiino-tekhnichnoi osvity NAPN Ukrainy. Ser.: Profesiina pedahohika. 2011, № 1. S. 87-93.

ГРИЖЕНКо В. В. Педагогическое проектирование как педагогическое условие развития профессиональных компетентостей преподавателей учреждений профессиональнотехнического образования.

В статье раскрыто сущностные характеристики педагогического проектирования как педагогического условия развития профессиональных компетентостей преподавателей учреждений профессионально-технического образования. Охарактеризованы особенности проектной деятельности для преподавателей учреждений профессионально-технического образования. Представлены различные взгляды ученьл на сущность исследуемого понятия. Определень принципь педагогического проектирования. Доказана важность использования технологий педагогического проектирования в профессионально-технических учебных заведениях. Вылелены структурные компоненты педагогического проектирования.

Ключевые слова: педагогическое проектирование, педагогическое условие, преподаватель, профессионально-техническое образование.

Hryzhenko V. V. Pedagogical design as a pedagogical condition for the development of professional competences of teachers of vocational education institutions.

The article describes the essential characteristics of pedagogical design as a pedagogical condition for the development of professional competences of teachers of vocational education institutions. The peculiarities of the project activity for teachers of vocational education institutions are described. Different views of scientists on the essence of the studied concept are presented. The principles of pedagogical design are defined. The importance of the use of pedagogical design technologies in vocational schools has been proved. Structural components of pedagogical design are distinguished.

Keywords: pedagogical design, pedagogical condition, teacher, vocational education. 